\title{
Syntrophomonas palmitatica sp. nov., an anaerobic, syntrophic, long-chain fatty-acid-oxidizing bacterium isolated from methanogenic sludge
}

\author{
Correspondence \\ Hiroyuki Imachi \\ imachi@jamstec.go.jp
}

\author{
Masashi Hatamoto, ${ }^{1}$ Hiroyuki Imachi, ${ }^{1,2}$ Sanae Fukayo, ${ }^{1}$ Akiyoshi Ohashi ${ }^{1}$ \\ and Hideki Harada ${ }^{1,3}$
${ }^{1}$ Department of Environmental Systems Engineering, Nagaoka University of Technology, Nagaoka, Niigata 940-2188, Japan
${ }^{2}$ Subground Animalcule Retrieval (SUGAR) Program, Extremobiosphere Research Center, Japan Agency for Marine-Earth Science and Technology (JAMSTEC), Yokosuka, Kanagawa 237-0061, Japan
${ }^{3}$ Department of Civil Engineering, Tohoku University, Sendai, Miyagi 980-8579, Japan

\begin{abstract}
A mesophilic, syntrophic, fatty-acid-oxidizing anaerobic strain, designated $\mathrm{MPA}^{\top}$, was isolated from granular sludge in a mesophilic upflow anaerobic sludge blanket reactor used to treat palm oil mill effluent. Cells were slightly curved, non-motile rods. Spore formation was not observed. The optimal temperature for growth was around $37{ }^{\circ} \mathrm{C}$ and optimal $\mathrm{pH}$ for growth was 7.0. Strain $\mathrm{MPA}^{\top}$ was able to grow on crotonate or pentenoate plus butyrate in pure culture. In co-culture with the hydrogenotrophic methanogen Methanospirillum hungatei, strain $\mathrm{MPA}^{\top}$ was able to oxidize straight-chain saturated fatty acids with carbon chain lengths of $\mathrm{C} 4-\mathrm{C} 18$. The strain was unable to utilize sulfate, sulfite, thiosulfate, nitrate, fumarate, iron(III) or DMSO as an electron acceptor. The $G+C$ content of the DNA was 45.0 mol\%. Based on comparative 16S rRNA gene sequence analysis, strain MPA ${ }^{\top}$ was found to be a member of the genus Syntrophomonas and was most closely related to the type strains of Syntrophomonas curvata and Syntrophomonas sapovorans (sequence similarities of $94 \%$ ). Genetic and phenotypic characteristics demonstrated that strain MPA ${ }^{\top}$ represents a novel species, for which the name Syntrophomonas palmitatica sp. nov. is proposed. The type strain is $\mathrm{MPA}^{\top}\left(=\mathrm{JCM} 14374^{\top}=\mathrm{NBRC}\right.$ $102128^{\top}=$ DSM $18709^{\top}$ ).
\end{abstract}

Natural lipids such as fats and oils are hydrolysed to longchain fatty acids (LCFAs) and glycerol. Under methanogenic conditions, LCFAs are further degraded by the syntrophic association of LCFA-oxidizing, hydrogen (and/ or formate)-producing fermentative bacteria and hydrogenotrophic methanogens, because the oxidation of LCFAs is thermodynamically unfavourable in such environments unless the consumption of hydrogen and/or formate is coupled with oxidation (Schink, 1997). Therefore, LCFAdegrading anaerobes can gain only a small amount of energy through these syntrophic reactions and thus their growth is generally slow. In addition, LCFAs can cause

Abbreviations: FAME, fatty acid methyl ester; LCFA, long-chain fatty acid.

The GenBank/EMBL/DDBJ accession numbers for the $r$ rnA and $r r n B$ operons of the 16S rRNA gene sequence of strain $\mathrm{MPA}^{\top}$ are AB274039 and AB274040, respectively.

A phase-contrast micrograph showing the cell morphology of strain $M A^{\top}$ is available as supplementary material with the online version of this paper. substrate toxicity in microbes. Consequently, isolation of LCFA-degrading bacteria has been difficult and, at the time of writing, only six species/subspecies have been described. Five of these belong to the family Syntrophomonadaceae within the phylum Firmicutes: Syntrophomonas sapovorans (Roy et al., 1986), Syntrophomonas wolfei subsp. saponavida (Lorowitz et al., 1989), Thermosyntropha lipolytica (Svetlitshnyi et al., 1996), Syntrophomonas curvata (Zhang et al., 2004) and the very recently described Syntrophomonas zehnderi (Sousa et al., 2007). There is only one species described to date belonging to the class Deltaproteobacteria, i.e. Syntrophus aciditrophicus (Jackson et al., 1999), which also degrades LCFAs syntrophically.

Recently, we successfully isolated strain $\mathrm{MPA}^{\mathrm{T}}$ from methanogenic granular sludge that was taken from palm oil mill effluent treated in a mesophilic upflow anaerobic sludge blanket reactor (Hatamoto et al., 2007). In a previous study, strain $\mathrm{MPA}^{\mathrm{T}}$ was found to be able to grow on palmitate in co-culture with the hydrogenotrophic methanogen Methanospirillum hungatei JF- $1^{\mathrm{T}}\left(\mathrm{DSM} 864^{\mathrm{T}}\right)$. 
Partial 16S rRNA gene sequence analysis revealed that strain $\mathrm{MPA}^{\mathrm{T}}$ was affiliated with the genus Syntrophomonas, but was only distantly related to any recognized species. In the present report, we describe the detailed morphological and physiological characteristics of strain $\mathrm{MPA}^{\mathrm{T}}$ and propose a novel species to accommodate it.

Strain $\mathrm{MPA}^{\mathrm{T}}$ was isolated from a methanogenic granular sludge by using conventional techniques combined with in situ hybridization detection via a 16S rRNA-targeted fluorescently labelled oligonucleotide probe (Hatamoto et al., 2007). Media for cultivation of strain $\mathrm{MPA}^{\mathrm{T}}$ were prepared as described by Sekiguchi et al. (2000). Strain $\mathrm{MPA}^{\mathrm{T}}$ formed small, white-brownish lens-shaped colonies of $0.5-1 \mathrm{~mm}$ in diameter on agar roll tube medium with $20 \mathrm{mM}$ crotonate after 1 month incubation. Cell morphologies were observed under a fluorescent microscope (Olympus BX50F). Cells of strain $\mathrm{MPA}^{\mathrm{T}}$ were non-motile, curved rods $1.5-4.0 \mu \mathrm{m}$ long and $0.4-0.6 \mu \mathrm{m}$ wide with round ends (see Supplementary Fig. S1 in IJSEM Online). Cells were Gram-negative according to the method of Hucker (Doetsch, 1981). Spores were not observed in pure culture or co-culture with $M$. hungatei.

Strain $\mathrm{MPA}^{\mathrm{T}}$ was strictly anaerobic as no growth occurred under trace quantities of oxygen [0.1 and $0.2 \% \mathrm{O}_{2}(\mathrm{v} / \mathrm{v})$ ]. Growth in pure culture was observed on crotonate or butyrate plus pentenoate as an energy source. Yeast extract $(0.05 \%)$ was not required but did stimulate growth. For determination of the fermentation products of strain $\mathrm{MPA}^{\mathrm{T}}$, we used a GC-TCD (gas chromatograph equipped with thermal conductivity detector) and GC-FID (gas chromatograph equipped with flame ionization detector) as described by Kucivilize et al. (2003), and HPLC as described by Imachi et al. (2002). Fermentation products from crotonate were butyrate and acetate; 1 mol crotonate was converted to $0.2 \mathrm{~mol}$ butyrate and $1.5 \mathrm{~mol}$ acetate after 14 days (90\% electron recovery). During incubation with crotonate in pure culture, hydrogen was always below $30 \mathrm{~Pa}$ in the gas phase. The following substrates did not serve as sole carbon and energy source (increase of turbidity was not observed after 3 months incubation, duplicate cultures): yeast extract $(0.2 \%)$, tryptone $(0.2 \%)$, Casamino acids $(0.2 \%)$, glucose $(10 \mathrm{mM})$, sucrose $(10 \mathrm{mM})$, ribose $(10 \mathrm{mM})$, xylose $(10 \mathrm{mM})$, acetate $(20 \mathrm{mM})$, propionate $(10 \mathrm{mM})$, butyrate $(20 \mathrm{mM})$, isobutyrate $(20 \mathrm{mM})$, straight-chain fatty acids from C5 to C8 (5 mM), straight-chain fatty acids from $\mathrm{C} 10$ to $\mathrm{C} 18$ $\left(1 \mathrm{mM}+1 \mathrm{mM} \quad \mathrm{CaCl}_{2}\right)$, oleate $(1 \mathrm{mM})$ plus $\mathrm{CaCl}_{2}$ $(1 \mathrm{mM})$, linoleate $(1 \mathrm{mM})$ plus $\mathrm{CaCl}_{2}(1 \mathrm{mM})$, pentenoate $(10 \mathrm{mM})$, fumarate $(10 \mathrm{mM})$, malate $(10 \mathrm{mM})$, succinate $(10 \mathrm{mM})$, formate $(10 \mathrm{mM})$, lactate $(10 \mathrm{mM})$, glycerol $(5 \mathrm{mM})$, ethanol $(10 \mathrm{mM})$, 1-propanol $(10 \mathrm{mM})$ and benzoate $(5 \mathrm{mM})$. The following were tested as electron acceptors with butyrate $(20 \mathrm{mM})$ and yeast extract $(0.05 \%)$ as electron donor, but none of them was utilized: sulfate $(20 \mathrm{mM})$, sulfite $(2 \mathrm{mM})$, thiosulfate $(20 \mathrm{mM})$, nitrate $(20 \mathrm{mM})$, fumarate $(20 \mathrm{mM})$, iron(III)-nitrilotriacetate $(5 \mathrm{mM})$ and DMSO $(10 \mathrm{mM})$.
Substrate utilization of strain $\mathrm{MPA}^{\mathrm{T}}$ in co-culture with $M$. hungatei was investigated for the same substrates used in the pure culture study. Only the following substrates were used and produced methane within 3 months of cultivation: butyrate $(20 \mathrm{mM})$, straight-chain saturated fatty acids from $\mathrm{C} 5$ to $\mathrm{C} 8(5 \mathrm{mM})$, straight-chain saturated fatty acids from $\mathrm{C} 10$ to $\mathrm{C} 18(1 \mathrm{mM}+1 \mathrm{mM} \mathrm{CaCl} 2)$ and pentenoate $(10 \mathrm{mM})$. As shown in Fig. 1, palmitate was completely degraded and transformed into acetate and methane within 2 weeks of incubation in co-culture with $M$. hungatei (106\% electron recovery). The growth rate of the strain in co-culture with $M$. hungatei on palmitate $(1 \mathrm{mM})$ was approximately 1.2 day $^{-1}$ (determined by measuring methane production). Fatty acids with an even number of carbon atoms were converted into acetate and methane, whereas those with an odd number of carbon atoms were converted into propionate and methane, implying that $\beta$ oxidation of fatty acids was performed by the co-culture.

Effects of $\mathrm{pH}$, temperature and $\mathrm{NaCl}$ on growth rate were determined by using the basal medium containing $10 \mathrm{mM}$ crotonate plus $0.05 \%$ yeast extract with $2 \% \quad(\mathrm{v} / \mathrm{v})$ inoculum. Growth rate was determined by measuring the $\mathrm{OD}_{600}$. To determine the optimum $\mathrm{pH}$ for strain $\mathrm{MPA}^{\mathrm{T}}$, the initial $\mathrm{pH}$ of the crotonate medium was adjusted to $5.5-9.0$ by adding $\mathrm{HCl}$ or $\mathrm{NaOH}$ under a $100 \% \mathrm{~N}_{2}$ atmosphere at room temperature, and the strain was then incubated at $37{ }^{\circ} \mathrm{C}$ in triplicate. Under these conditions, the $\mathrm{pH}$ range for growth was 6.5-8.0 with optimum growth at $\mathrm{pH}$ 7.0. For determinations of the optimum temperature for growth, cultures were incubated at 25, 30, 35, 37, 40, 45, 50 and $55{ }^{\circ} \mathrm{C}$ in duplicate. The strain grew optimally at $37^{\circ} \mathrm{C}$; no growth was observed at 25 or $55{ }^{\circ} \mathrm{C}$. The $\mathrm{NaCl}$ tolerance concentration range was 1-200 $\mathrm{mM}$ (growth was improved at below $25 \mathrm{mM} \mathrm{NaCl}$ ) determined in duplicate incubations. Under optimum conditions $\left(\mathrm{pH} 7.0,37^{\circ} \mathrm{C}\right)$,

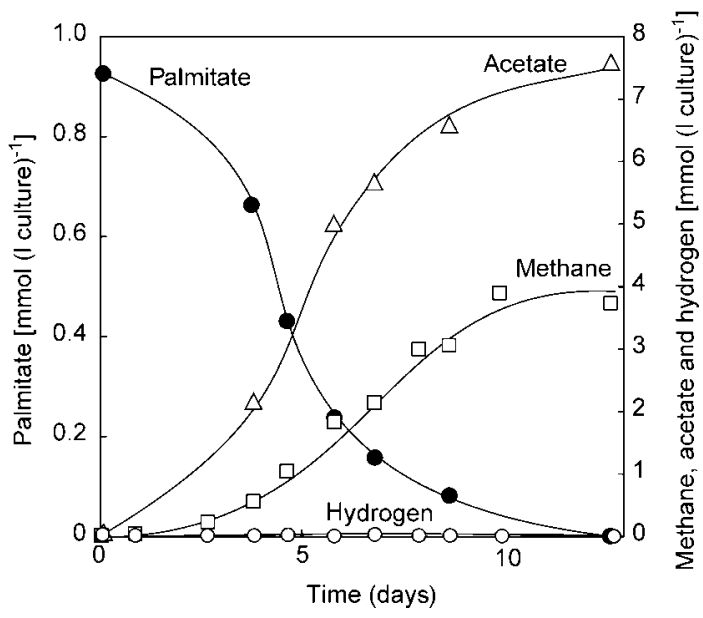

Fig. 1. Degradation of palmitate and production of acetate, methane and hydrogen by strain $\mathrm{MPA}^{\top}$ in co-culture with $M$. hungatei $\mathrm{JF}-1^{\top}$. 
the growth rate of the strain in pure culture on crotonate was $1.07 \pm 0.02 \mathrm{day}^{-1}$ (triplicate determinations). This growth rate was about the same order as that of Syntrophomonas wolfei subsp. wolfei or the thermophilic species Syntrophothermus lipocalidus [0.7 and 0.9 day $^{-1}$, respectively (Beaty \& McInerney, 1987; Sekiguchi et al., 2000)] but was slower than that for Syntrophomonas curvata (2.2 day ${ }^{-1}$; Zhang et al., 2004).

The effect of antibiotics on growth of strain $\mathrm{MPA}^{\mathrm{T}}$ was tested under optimum cultivation conditions by using $10 \mathrm{mM}$ crotonate supplemented with $0.05 \%$ yeast extract as a substrate. The strain was able to tolerate ampicillin $\left(50 \mu \mathrm{g} \mathrm{ml}^{-1}\right)$, but rifampicin, chloramphenicol, kanamycin, neomycin and vancomycin (all at $50 \mu \mathrm{g} \mathrm{ml}^{-1}$ ) completely inhibited growth.

For determination of the DNA base composition, DNA was extracted and purified according to the method of Kamagata \& Mikami (1991). The DNA G + C content of strain $\mathrm{MPA}^{\mathrm{T}}$ was $45.0 \mathrm{~mol} \%$, as determined by direct analysis of deoxyribonucleotides by HPLC (Tamaoka \& Komagata, 1984). For fatty acid methyl ester (FAME) analysis, cells of strain $\mathrm{MPA}^{\mathrm{T}}$ grown on $20 \mathrm{mM}$ crotonate plus $0.05 \%$ yeast extract were harvested. Extraction of cellular fatty acids and methylation were performed as described by Takai et al. (2004). The FAMEs were analysed via GC-MS (TRACE GC ULTRA + DSQ system; Thermo electron). The major fatty acids of strain $\mathrm{MPA}^{\mathrm{T}}$ were $\mathrm{C}_{14: 0}$ (27.1\% of total fatty acids), $\mathrm{C}_{16: 0}(19.8 \%), \mathrm{C}_{18: 0}(17.5 \%)$, $\mathrm{C}_{16: 1}(15.9 \%), \mathrm{C}_{15: 0}(7.7 \%)$ and $\mathrm{C}_{18: 1}(3.8 \%)$.

Directly extracted DNA from a pure culture of strain $\mathrm{MPA}^{\mathrm{T}}$ was used for amplification of the 16S rRNA gene by using bacterial $8 \mathrm{f}$ and universal 1490r primer sets (Weisburg et al., 1991) and sequenced by using the methods of Qiu et al. (2004). Sequencing results revealed that in the V1 region of the 16S rRNA gene sequence fragment peaks overlapped, suggesting that several sequences existed, but the rest of the 16S rRNA gene sequences were unambiguous. We therefore speculated that strain $\mathrm{MPA}^{\mathrm{T}}$ has sequence heterogeneities in the $r r$ operons. The PCR products were purified with a MinElute PCR purification kit (Qiagen), followed by cloning with a TOPO TA cloning kit (Invitrogen). Ten clonal rRNA genes were randomly picked and sequenced. We found two types of 16S rRNA gene sequences and these were identical except for the $\mathrm{V} 1$ region. We designated the shorter sequence as $r r n A$ (1571 bp, 6/10 clones) and the longer one as $\mathrm{rrnB}$ (1589 bp, 4/10 clones). Although we repeatedly isolated strain $\mathrm{MPA}^{\mathrm{T}}$ by single colony isolation from roll tubes, there is a slight possibility that two closely related species were isolated. To exclude this possibility, fluorescence in situ hybridization was applied for both sequences in individual cells. Two fluorescently labelled oligonucleotide probes specific to each $r r n$ sequence were designed to determine whether the $r r n A$ and $r r n B$ sequences belonged to a single cell. However, for a variety of hybridization conditions, we were unable to detect positive signals from these newly designed probes (data not shown), despite observing hybridization of a previously designed strain $\mathrm{MPA}^{\mathrm{T}}$-targeted probe MPA1446 (Hatamoto et al., 2007). This could be due to the relative accessibility of the target sites (Amann et al., 1995). Alternatively, the 16S rRNA gene target may not be transcribed, as in Clostridium paradoxum (Rainey et al., 1996), or the target may be transcribed but excised during rRNA maturation (Evguenieva-Hackenberg, 2005). Consequently, we confirmed the $16 \mathrm{~S}$ rRNA gene sequence of strain $\mathrm{MPA}^{\mathrm{T}}$. We extracted total RNA, by using the method described by Sekiguchi et al. (2005), from crotonate-grown cultures of strain $\mathrm{MPA}^{\mathrm{T}}$ and this was reverse transcribed by using SuperScript III Reverse Transcriptase (Invitrogen) with a primer complementary to the 530f primer (Lane, 1991). The resulting cDNA was used for PCR amplification with the 8f/530r primer set and the products were sequenced. Only the 16S rRNA gene sequence of $r r n A$ was detected, suggesting that strain $\mathrm{MPA}^{\mathrm{T}}$ has one type of $16 \mathrm{~S}$ rRNA. Based on these results, and given the fact that multiple numbers and heterogeneity of $16 \mathrm{~S}$ rRNA genes are common phenomena (Acinas et al., 2004), we conclude that strain $\mathrm{MPA}^{\mathrm{T}}$ has two types of $16 \mathrm{~S}$ rRNA gene sequence but that only the rrnA type of $16 \mathrm{~S}$ rRNA was transcribed.

Comparative 16S rRNA gene sequence phylogenetic analysis was performed as described by Hatamoto et al. (2007). Bootstrap resampling analysis was performed with the neighbour-joining, maximum-parsimony and maximum-likelihood methods to estimate the confidence of tree topologies, as described by Sekiguchi et al. (2006). A phylogenetic tree including $r r n A$ and $r r n B$ 16S rRNA gene sequences of strain $\mathrm{MPA}^{\mathrm{T}}$ and other members of the family Syntrophomonadaceae was constructed (Fig. 2). The phylogenetic analysis indicated that strain $\mathrm{MPA}^{\mathrm{T}}$ was affiliated with the genus Syntrophomonas. The closest relatives of strain $\mathrm{MPA}^{\mathrm{T}}$ were the type strains of Syntrophomonas curvata and Syntrophomonas sapovorans (both having similarity values of $94 \%$ for $r r n A$ and $r r n B$ ).

Based on these results, strain $\mathrm{MPA}^{\mathrm{T}}$ is considered to represent a member of the genus Syntrophomonas. Strain $\mathrm{MPA}^{\mathrm{T}}$ and other Syntrophomonas species share common phenotypic features (Table 1), particularly syntrophic growth with hydrogenotrophic methanogens on shortchain fatty acids and the inability to utilize external electron acceptors. However, strain $\mathrm{MPA}^{\mathrm{T}}$ differs from Syntrophomonas curvata and Syntrophomonas sapovorans in growth temperature and $\mathrm{pH}$ range for growth (Table 1). The FAME profile of strain MPA ${ }^{\mathrm{T}}$ differed from those of other Syntrophomonas species, with strain $\mathrm{MPA}^{\mathrm{T}}$ having $\mathrm{C}_{18: 0}$ as one of the predominant fatty acids (Henson et al., 1988; Zhang et al., 2004, 2005). Although strain $\mathrm{MPA}^{\mathrm{T}}$ has almost the same substrate range as Syntrophomonas curvata, the mechanism of degradation of crotonate in pure culture is different, i.e. Syntrophomonas curvata converts $1 \mathrm{~mol}$ crotonate to $0.5 \mathrm{~mol}$ butyrate and $1 \mathrm{~mol}$ acetate (Zhang et al., 2004). By contrast, strain $\mathrm{MPA}^{\mathrm{T}}$ 


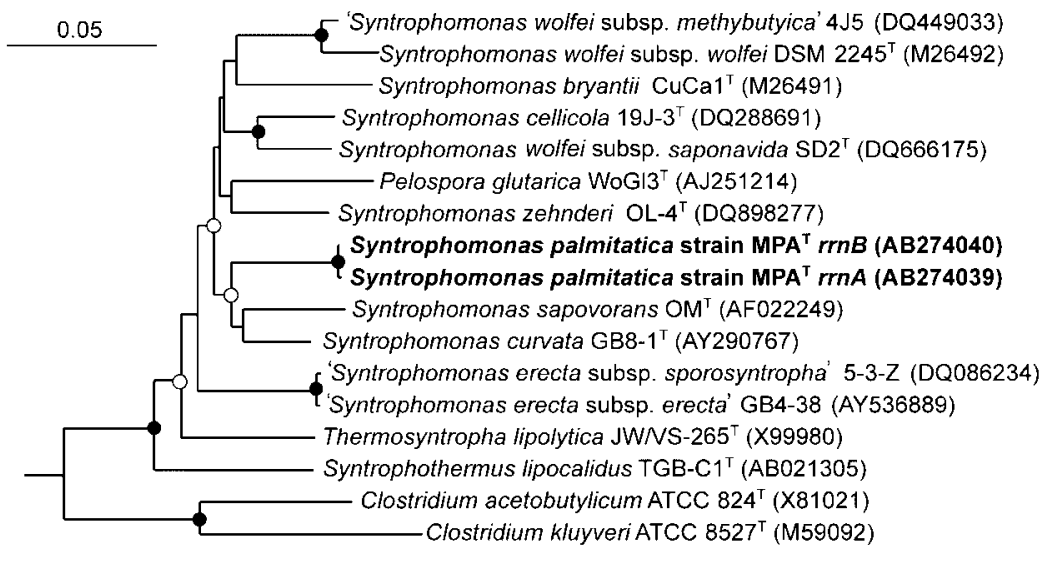

Fig. 2. Phylogenetic position of strain $M P A^{\top}$ and related organisms. The tree was calculated based on a distance matrix analysis of 16S rRNA gene sequences (neighbour-joining tree). The 16S rRNA gene sequence of Arthrobacter globiformis DSM $20124^{\top}$ (X80736) was used to root the tree (not shown). Branching points supported with probabilities above $90 \%$ by all the analyses (based on 1000 replicates, estimated by using the neighbour-joining, maximum-parsimony and maximum-likelihood methods) are indicated by a solid circle, whereas nodes with open circles indicate $>70 \%$ bootstrap probability support by the three analyses. The accession number of each reference sequence is shown in parentheses. Bar, 0.05 nucleotide changes per sequence position.

converts $1 \mathrm{~mol}$ crotonate to $0.2 \mathrm{~mol}$ butyrate and $1.5 \mathrm{~mol}$ acetate, similar to Syntrophomonas wolfei subsp. wolfei. However, Syntrophomonas wolfei subsp. wolfei is unable to degrade LCFAs in co-culture with methanogens, whereas strain $\mathrm{MPA}^{\mathrm{T}}$ can (Table 1). Based on the phenotypic features of strain $\mathrm{MPA}^{\mathrm{T}}$ as well as its $16 \mathrm{~S}$ rRNA gene sequence divergence, we consider that strain $\mathrm{MPA}^{\mathrm{T}}$ represents a novel species of the genus Syntrophomonas,

Table 1. Characteristics of strain $\mathrm{MPA}^{\top}$ (Syntrophomonas palmitatica sp. nov.) and related organisms in the family Syntrophomonadaceae

Reference strains: 1, Syntrophomonas sapovorans $\mathrm{OM}^{\mathrm{T}}$ (data from Roy et al., 1986; Zhang et al., 2005); 2, Syntrophomonas curvata GB8-1 ${ }^{\mathrm{T}}$ (Zhang et al., 2004, 2005); 3, Syntrophomonas saponavida SD2 ${ }^{\mathrm{T}}$ (Lorowitz et al., 1989); 4, Syntrophomonas wolfei subsp. wolfei DSM $2245^{\mathrm{T}}$ (McInerney et al., 1979, 1981; Beaty \& McInerney, 1987; Zhang et al., 2005); 5, Syntrophomonas bryantii CuCa1 ${ }^{\mathrm{T}}$ (Stieb \& Schink, 1985; Zhao et al., 1990; Wu et al., 2006). In co-culture with methanogens, all strains can use straight-chain fatty acids with butyrate to caprylate, whereas all strains cannot use propionate. ND, Not determined; - , negative; + , positive; \pm , variable.

\begin{tabular}{|c|c|c|c|c|c|c|}
\hline Characteristic & Strain $\mathrm{MPA}^{\mathrm{T}}$ & 1 & 2 & 3 & 4 & 5 \\
\hline Cell width $(\mu \mathrm{m})$ & $0.4-0.6$ & 0.5 & $0.5-0.7$ & $0.4-0.6$ & $0.5-1.0$ & 0.4 \\
\hline Cell length $(\mu \mathrm{m})$ & $1.5-4.0$ & 2.5 & $2.3-4.0$ & $2.0-4.0$ & $2.0-7.0$ & $4.5-6.0$ \\
\hline Gram reaction & - & - & \pm & - & - & \pm \\
\hline Motility & - & + & + & + & + & - \\
\hline DNA G $+C$ content $(\mathrm{mol} \%)$ & 45.0 & $\mathrm{ND}$ & 46.6 & $\mathrm{ND}$ & 45.1 & 37.6 \\
\hline Growth $\mathrm{pH}$ (range/optimum) & $6.5-8.0 / 7.0$ & $6.3-8.1 / 7.3$ & $6.3-8.4 / 7.5$ & $\mathrm{ND}$ & $6.2-8.1 / 7.0-7.5$ & $6.5-7.5 / \mathrm{ND}$ \\
\hline $\begin{array}{l}\text { Growth temperature (range/ } \\
\text { optimum })\left({ }^{\circ} \mathrm{C}\right)\end{array}$ & $30-50 / 37$ & $25-45 / 35-37$ & $20-42 / 35-37$ & ND & $25-45 / 35-37$ & $20-40 / 28-34$ \\
\hline \multicolumn{7}{|c|}{ Substrate utilization in pure culture: } \\
\hline Crotonate & + & - & + & + & + & + \\
\hline Butyrate + pentenoate & + & - & + & ND & - & - \\
\hline \multicolumn{7}{|c|}{$\begin{array}{l}\text { Substrate utilization in co-culture } \\
\text { with methanogens: }\end{array}$} \\
\hline Acetate & - & - & - & ND & - & ND \\
\hline Caprate & + & + & + & + & - & + \\
\hline Laurate & + & + & + & + & - & - \\
\hline Myristate & + & + & + & + & - & - \\
\hline Palmitate & + & + & + & + & - & - \\
\hline Stearate & + & + & + & + & - & - \\
\hline Oleate & - & + & + & - & - & ND \\
\hline Linoleate & - & + & - & - & - & ND \\
\hline
\end{tabular}


for which the name Syntrophomonas palmitatica sp. nov. is proposed.

\section{Description of Syntrophomonas palmitatica sp. nov.}

Syntrophomonas palmitatica (pal.mi.ta'ti.ca. N.L. n. palmitas-atis palmitate; L. suff. -icus - $a$-um suffix used with the sense of belonging to; N.L. fem. adj. palmitatica belonging to palmitate).

Cells are slightly curved rods, $1.5-4.0 \mu \mathrm{m}$ long and $0.4-$ $0.6 \mu \mathrm{m}$ wide. Strictly anaerobic and Gram-negative. Can grow in pure culture on crotonate or pentenoate plus butyrate. Does not utilize sulfate, sulfite, thiosulfate, nitrate, fumarate, iron(III)-nitrilotriacetate or DMSO as electron acceptors. In syntrophic association with hydrogenotrophic methanogens, can utilize straight-chain saturated fatty acids with 4-18 carbon atoms. Acetate, propionate, iso-butyrate and benzoate do not support growth of the co-culture. Temperature range for growth is $30-50{ }^{\circ} \mathrm{C}$ (optimum, $37{ }^{\circ} \mathrm{C}$ ). $\mathrm{pH}$ range for growth is $6.5-$ 8.0 (optimum, $\mathrm{pH} 7.0$ ). The $\mathrm{G}+\mathrm{C}$ content of the DNA of the type strain is $45.0 \mathrm{~mol} \%$.

The type strain, $\mathrm{MPA}^{\mathrm{T}} \quad\left(=\mathrm{JCM} \quad 14374^{\mathrm{T}}=\mathrm{NBRC}\right.$ $102128^{\mathrm{T}}=$ DSM $18709^{\mathrm{T}}$ ), was isolated from granular sludge of an upflow anaerobic sludge blanket reactor treating palm oil mill effluent.

\section{Acknowledgements}

We thank Satoshi Nakagawa and Masayuki Miyazaki at JAMSTEC for FAME analysis and measurement of DNA G+C contents, respectively. We also thank Diana Z. Sousa at the University of Minho for providing sequence information of Syntrophomonas zhenderi. This study was financially supported by the New Energy and Industrial Technology Development Organization (NEDO), Japan Society for the Promotion of Science, Institute for Fermentation, Osaka, and the 21st Century COE program 'Global Renaissance by Green Energy Revolution' subsidized by the Japanese Ministry of Education, Culture, Sports, Science and Technology, Tokyo, Japan.

\section{References}

Acinas, S. G., Marcelino, L. A., Klepac-Ceraj, V. \& Polz, M. F. (2004). Divergence and redundancy of $16 \mathrm{~S}$ rRNA sequences in genomes with multiple rrn operons. J Bacteriol 186, 2629-2635.

Amann, R. I., Ludwig, W. \& Schleifer, K. H. (1995). Phylogenetic identification and in situ detection of individual microbial cells without cultivation. Microbiol Rev 59, 143-169.

Beaty, P. S. \& McInerney, M. J. (1987). Growth of Syntrophomonas wolfei in pure culture on crotonate. Arch Microbiol 147, 389-393.

Doetsch, R. N. (1981). Determinative methods of light microscopy. In Manual of Methods for General Bacteriology, pp. 21-33. Edited by P. Gerhardt, R. G. E. Murray, R. N. Costilow, E. W. Nester, W. A. Wood, N. R. Krieg \& G. B. Phillips. Washington, DC: American Society for Microbiology.

Evguenieva-Hackenberg, E. (2005). Bacterial ribosomal RNA in pieces. Mol Microbiol 57, 318-325.
Hatamoto, M., Imachi, H., Ohashi, A. \& Harada, H. (2007). Identification and cultivation of anaerobic, syntrophic long-chain fatty acid degrading microbes from mesophilic and thermophilic methanogenic sludges. Appl Environ Microbiol 73, 1332-1340.

Henson, J. M., Mclnerney, M. J., Beaty, P. S., Nickels, J. \& White, D. C. (1988). Phospholipid fatty acid composition of the syntrophic anaerobic bacterium Syntrophomonas wolfei. Appl Environ Microbiol 54, 1570-1574.

Imachi, H., Sekiguchi, Y., Kamagata, Y., Hanada, S., Ohashi, A. \& Harada, H. (2002). Pelotomaculum thermopropionicum gen. nov., sp. nov., an anaerobic, thermophilic, syntrophic propionate-oxidizing bacterium. Int J Syst Evol Microbiol 52, 1729-1735.

Jackson, B. E., Bhupathiraju, V. K., Tanner, R. S., Woese, C. R. \& McInerney, M. J. (1999). Syntrophus aciditrophicus sp. nov., a new anaerobic bacterium that degrades fatty acids and benzoate in syntrophic association with hydrogen-using microorganisms. Arch Microbiol 171, 107-114.

Kamagata, Y. \& Mikami, E. (1991). Isolation and characterization of a novel thermophilic Methanosaeta strain. Int J Syst Bacteriol 41, 191-196.

Kucivilize, P., Ohashi, A. \& Harada, H. (2003). Process performance and sludge behaviors of multi-staged UASB reactor for treatment of palm oil mill effluent (POME). Environ Eng Res 40, 441-449 (in Japanese)

Lane, D. J. (1991). 16S/23S rRNA sequencing. In Nucleic Acid Techniques in Bacterial Systematics, pp. 115-175. Edited by E. Stackebrandt \& M. Goodfellow. Chichester: Wiley.

Lorowitz, W. H., Zhao, H. \& Bryant, M. P. (1989). Syntrophomonas wolfei subsp. saponavida subsp. nov., a long-chain fatty-aciddegrading, anaerobic, syntrophic bacterium; Syntrophomonas wolfei subsp. wolfei subsp. nov.; and emended descriptions of the genus and species. Int J Syst Bacteriol 39, 122-126.

Mclnerney, M. J., Bryant, M. P. \& Pfennig, N. (1979). Anaerobic bacterium that degrades fatty acids in syntrophic association with methanogens. Arch Microbiol 122, 129-135.

Mclnerney, M. J., Bryant, M. P., Hespell, R. B. \& Costerton, J. W. (1981). Syntrophomonas wolfei gen. nov. sp. nov., an anaerobic, syntrophic, fatty acid-oxidizing bacterium. Appl Environ Microbiol 41, 1029-1039.

Qiu, Y. L., Sekiguchi, Y., Imachi, H., Kamagata, Y., Tseng, I. C., Cheng, S. S., Ohashi, A. \& Harada, H. (2004). Identification and isolation of anaerobic, syntrophic phthalate isomer-degrading microbes from methanogenic sludges treating wastewater from terephthalate manufacturing. Appl Environ Microbiol 70, 1617-1626.

Rainey, F. A., Ward-Rainey, N. L., Janssen, P. H., Hippe, H. \& Stackebrandt, E. (1996). Clostridium paradoxum DSM $7308^{\mathrm{T}}$ contains multiple 16S rRNA genes with heterogeneous intervening sequences. Microbiology 142, 2087-2095.

Roy, F., Samain, E., Dubourguier, H. C. \& Albagac, G. (1986). Syntrophomonas sapovorans sp. nov., a new obligately proton reducing anaerobe oxidizing saturated and unsaturated long chain fatty acids. Arch Microbiol 145, 142-147.

Schink, B. (1997). Energetics of syntrophic cooperation in methanogenic degradation. Microbiol Mol Biol Rev 61, 262-280.

Sekiguchi, Y., Kamagata, Y., Nakamura, K., Ohashi, A. \& Harada, H. (2000). Syntrophothermus lipocalidus gen. nov., sp. nov., a novel thermophilic, syntrophic, fatty-acid-oxidizing anaerobe which utilizes isobutyrate. Int J Syst Evol Microbiol 50, 771-779.

Sekiguchi, Y., Uyeno, Y., Sunaga, A., Yoshida, H. \& Kamagata, Y. (2005). Sequence-specific cleavage of $16 \mathrm{~S}$ rRNA for rapid and quantitative detection of particular groups of anaerobes in bioreactors. Water Sci Technol 52, 107-113. 
Sekiguchi, Y., Imachi, H., Susilorukmi, A., Muramatsu, M., Ohashi, A., Harada, H., Hanada, S. \& Kamagata, Y. (2006). Tepidanaerobacter syntrophicus gen. nov., sp. nov., an anaerobic, moderately thermophilic, syntrophic alcohol- and lactate-degrading bacterium isolated from thermophilic digested sludges. Int J Syst Evol Microbiol 56, 1621-1629.

Sousa, D. Z., Smidt, H., Alves, M. M. \& Stams, A. J. M. (2007). Syntrophomonas zehnderi sp. nov., an anaerobe that degrades long chain fatty acids in co-culture with Methanobacterium formicicum. Int $J$ Syst Evol Microbiol 57, 609-615.

Stieb, M. \& Schink, B. (1985). Anaerobic oxidation of fatty acids by Clostridium bryantii sp. nov., a sporeforming, obligately syntrophic bacterium. Arch Microbiol 140, 387-390.

Svetlitshnyi, V., Rainey, F. \& Wiegel, J. (1996). Thermosyntropha lipolytica gen. nov., sp. nov., a lipolytic, anaerobic, alkalitolerant, thermophilic bacterium utilizing short- and long-chain fatty acids in syntrophic coculture with a methanogenic archaeum. Int $J$ Syst Bacteriol 46, 1131-1137.

Takai, K., Nealson, K. H. \& Horikoshi, K. (2004). Hydrogenimonas thermophila gen. nov., sp. nov., a novel thermophilic, hydrogenoxidizing chemolithoautotroph within the E-Proteobacteria, isolated from a black smoker in a Central Indian Ridge hydrothermal field. Int J Syst Evol Microbiol 54, 25-32.
Tamaoka, J. \& Komagata, K. (1984). Determination of DNA base composition by reversed-phase high-performance liquid chromatography. FEMS Microbiol Lett 25, 125-128.

Weisburg, W. G., Barns, S. M., Pelletier, D. A. \& Lane, D. J. (1991). $16 \mathrm{~S}$ ribosomal DNA amplification for phylogenetic study. J Bacteriol 173, 697-703.

Wu, C., Liu, X. \& Dong, X. (2006). Syntrophomonas cellicola sp. nov., a spore-forming syntrophic bacterium isolated from a distilled-spiritfermenting cellar, and assignment of Syntrophospora bryantii to Syntrophomonas bryantii comb. nov. Int J Syst Evol Microbiol 56, 2331-2335.

Zhang, C., Liu, X. \& Dong, X. (2004). Syntrophomonas curvata sp. nov., an anaerobe that degrades fatty acids in co-culture with methanogens. Int J Syst Evol Microbiol 54, 969-973.

Zhang, C., Liu, X. \& Dong, X. (2005). Syntrophomonas erecta sp. nov., a novel anaerobe that syntrophically degrades short-chain fatty acids. Int J Syst Evol Microbiol 55, 799-803.

Zhao, H. X., Yang, D. C., Woese, C. R. \& Bryant, M. P. (1990). Assignment of Clostridium bryantii to Syntrophospora bryantii gen. nov., comb. nov. on the basis of a 16S rRNA sequence analysis of its crotonate-grown pure culture. Int J Syst Bacteriol 40, 40-44. 